Çukurova Üniversitesi Mühendislik Mimarlık Fakültesi Dergisi, 32(3), ss. 175-185, Eylül 2017

\title{
Malahit Cevherinin Perklorik Asit Çözeltilerindeki Çözünürlüğünün İncelenmesi
}

\author{
Mehmet Kayra TANAYDIN ${ }^{1}$, Nizamettin DEMIRKIRAN ${ }^{* 2}$ \\ ${ }^{1}$ Munzur Üniversitesi Mühendislik Fakültesi Kimya Mühendisliği Bölümü, Tunceli \\ ${ }^{2}$ Inönü Üniversitesi Mühendislik Fakültesi Kimya Mühendisliği Bölümü, Malatya
}

Geliş tarihi: 06.06.2017 Kabul tarihi: 25.09.2017

Öz

Hidrometalurji sulu çözeltilerde kimyasal reaksiyonlar vasıtasıyla metal, metal tuzları ve bileşiklerinin üretimini kapsar. Oksitli bakır cevherlerindeki bakır, hidrometalurjik yöntemler yardımıyla kazanılabilir. Sözü edilen metodun ilk aşaması katı-sıvı kütle transferini içeren liç prosesidir. Bu proseste katı cevher uygun bir çözücü ile çözündürülür ve metal değerler çözelti ortamına transfer edilir. Mevcut çalışmada, oksitli bir bakır cevheri olan malahitin sulu perklorik asit çözeltilerindeki çözünürlüğü incelenmiştir. Malahit cevherindeki bakır, çinko ve demirin çözünme davranışı belirlenmiştir. Cevherdeki bakırın çözünürlüğü üzerine asit derişimi, reaksiyon sıcaklığı, ortalama katı tanecik boyutu, katı/sıvı oranı ve karıştırma hızının etkileri araştırılmıştır. Bütün deneysel parametrelerin bakırın çözünmesi üzerinde önemli bir etkiye sahip oldukları gözlenmiştir. Asit derişimi, reaksiyon sıcaklığı ve karıştırma hızının artmasıyla, katı/sıvı oranı ve katı tanecik boyutunun ise azalmasıyla cevherdeki bakır liçinin arttı̆̆ tespit edilmiştir. Cevherdeki demirin çözünürlüğünün asit derişiminden oldukça etkilendiği gözlenmiştir. Reaksiyon koşullarının kontrol edilmesiyle çözelti ortamına geçen bakır miktarının yüksek, demir miktarının ise düşük seviyelerde tutulabileceği belirlenmiştir. Liç prosesi ile ilgili kinetik analiz yapılmış ve reaksiyon hızının karışık kinetik kontrollü modele uyduğu belirlenmiştir. Liç prosesinin aktivasyon enerjisi 30,94 kJ/mol olarak hesaplanmıştır.

Anahtar Kelimeler: Malahit, Bakır, Liç, Perklorik asit

\section{Investigation of Dissolution of Malachite Ore in Perchloric Acid Solutions}

\begin{abstract}
Hydrometallurgy contains the production of metal, metal salts, and their compounds by means of chemical reactions in aqueous solutions. Copper in the oxidized copper ores can be recovered by hydrometallurgical methods. First step of the mentioned method is the leaching process involving a solid to liquid mass transfer. In this process, solid ore is dissolved by an appropriate solvent, and metal values are transferred into solution medium. In the present study, it was examined dissolution of malachite, which is an oxidized copper ore, in aqueous perchloric acid solutions. The dissolution behavior of copper, zinc, and iron in the malachite ore was determined. The effects of acid concentration, reaction temperature, average particle size of solid, solid-to-liquid ratio, and stirring speed on dissolution of
\end{abstract}

*Sorumlu yazar (Corresponding author): Nizamettin DEMIRKIRAN, nizamettin.demirkiran@inonu.edu.tr 
copper in the ore were investigated. It was observed that all experimental parameters have a significant effect on the leaching of copper. It was determined that the leaching of copper in the ore increased with an increase in acid concentration, reaction temperature and stirring speed, and with a decrease solid-toliquid ratio and in solid particle size. It was observed that the dissolution of iron in the ore was substantially affected from acid concentration. By controlling of the reaction conditions, it was found that the amount of copper passing to the solution medium can be high and the amount of iron can be kept at low levels. The kinetic analysis relating to the leaching process was made, and it was determined that the reaction rate followed the mixed kinetic controlled model. The activation energy of the leaching process was estimated to be $30.94 \mathrm{~kJ} / \mathrm{mol}$.

Keywords: Malachite, Copper, Leaching, Perchloric acid

\section{GİRIŞ}

Demir dışı metaller arasında bakır, çok eski zamanlardan beri kullanılmakta olup, elektrik ve 1sı iletkenliğinin yüksek oluşu, korozyona ve aşınmaya karşı direnci, bazı kimyasal maddelerin üretiminde katalizör olarak kullanılabilmesi ve çeşitli metallerle oluşturduğu alaşımlarının üstün özelliklerinden dolayı birçok alanda yaygın olarak kullanılan değerli bir metaldir. Bakır yer kabuğunda az bulunan oldukça değerli bir element olup, doğada az miktarda metalik halde bulunmakla birlikte genellikle oksitli, karbonatlı, silikatlı ve sülfürlü cevherleri halinde bulunur. Tabiatta bulunan bakır cevherlerinden ancak 10-15 kadarı ekonomik önem taşımaktadır. $\mathrm{Bu}$ cevherlerden bakır üretimi, hammadde olarak kullanılan cevherin türüne bağlı olarak pirometalurjik veya hidrometalurjik yöntemlerle yapilabilmektedir. Pirometalurjik yöntemler genellikle sülfürlü bakır cevherlerinden bakır üretiminde uygulanmaktadır. Son yıllarda bakır, bakır alaşımları ve bileşiklerine olan talebin artması, yüksek tenörlü sülfürlü bakır cevherlerinin azalması ve çevre kirliliğine karşı duyarlılı̆̆ın oluşması gibi sebeplerden ötürü düşük tenörlü oksitli/karbonatlı bakır cevherlerinin hidrometalurjik yöntemler uygulanarak değerlendirilmesine yönelik çalışmalar yapilmaktadır [1-6].

Hidrometalurji, sulu çözeltilerde gerçekleşen kimyasal reaksiyonlar vasitasiyla metal ve bileşiklerinin üretilmesi ile ilgili metotları kapsayan bir prosestir. Hidrometalurjide uygulanan işlemler katı yapıdaki cevherin bünyesinde bulunan metal değerin sulu çözelti ile reaksiyonu sonucu katı fazdan sıvı faza transfer olduğu liç işlemi, cevherin çözünmeyen kısmı ile çözeltinin ayrıldığı ayırma işlemi, metal değerleri içeren liç çözeltisinden istenmeyen metal iyonlarının uzaklaştırıldığı ayırma ve saflaştırma basamağ1 ve istenen metalin metalik halde veya bileşiği halinde elde edildiği kazanma basamaklarından oluşmaktadır. Gerek liç çözeltisinin saflaştırılması gerekse çözeltiden metal kazanılmasında çöktürme, iyon değişimi, solvent ekstraksiyonu, siv1 membran, sementasyon ve elektroliz gibi metotlar uygulanmaktadır $[1,7,8]$. Hidrometalurjik yöntemle bakır üretiminin ilk aşamasını cevherin sulu bir çözelti ile çözündürüldüğü liç işlemi oluşturur. Liç işleminin verimi hidrometalurjik prosesin sonraki adımlarını da yakından etkilemektedir. Dolayısıyla oksitli bakır cevherlerinden bakır elde etmek amaciyla yapılan çalışmalarda liç prosesi daha çok incelenmiştir.

Malahit en bilinen oksitli bakır cevherlerinden birisi olup çeşitli çözeltilerdeki çözünürlüğü farklı araștırmacılar tarafından incelenmiştir. Sulu sülfürik asit çözeltilerinde malahitin çözünürlüğü üzerine asit derişimi, reaksiyon sıcaklığ 1 , katı/sıv1 oranı, katı parçacık boyutu, karıştırma hız ve reaksiyon süresinin etkileri incelenmiş ve cevherdeki bakırın yüksek oranlarda çözündüğü tespit edilmiştir. Derişim, sıcaklık, karıştırma hızı ve sürenin liç işlemi üzerinde daha etkili parametreler olduğu belirlenmiştir [9]. Başka bir çalışmada malahit cevherinin sülfürik asit çözeltilerinde çözünürlüğü için optimum koşullar Taguchi metodu uygulanarak belirlenmiştir [10]. 
Özellikle demir iyonlarını içermeyen daha temiz liç çözeltileri elde etmek amacıyla amonyak [11], amonyum karbonat [12], amonyum klorür [13,14], amonyum sülfat [15], amonyum nitrat [16] ve amonyum asetat [17] gibi zayıf baz ve zayıf asidik özelliğe sahip kimyasalların sulu çözeltileri de malahit cevherinden bakırın çözündürülmesi için çözücü olarak kullanılmıştır.

Teknolojik gelişme ile birlikte bakıra olan talebin artması yüksek tenörlü sülfürlü bakır cevherlerinin yanı sıra düşük miktarlarda bakır içeren oksitli cevherlerin de ham madde kaynağı olarak değerlendirilmesine yol açmıştır. Böylece, ülkemizin farklı bölgelerinde dağılmış halde bulunan oksitli bakır cevherlerinin hidrometalurjik metotlar yardımıyla değerlendirilerek ekonomiye kazandırılması ülke ekonomisi bakımından son derece önemlidir. $\mathrm{Bu}$ düşünceden hareketle, malahit cevherinden liç, solvent ekstraksiyonu ve elektroliz metotların uygulanmasıyla metalik bakır üretimini amaçladığımız çalışmamızın ilk bölümü bu makalede sunulmuştur. Malahit cevherinin sulu perklorik asit çözeltilerinde çözündürülmesi üzerine asit derişimi, reaksiyon sıcaklığı, katı parçacık boyutu, katı/sıvı oranı ve karıştırma hızının etkileri incelenmiş ve elde edilen deneysel bulgular tartışılmıştır

\section{MATERYAL VE METOT}

\subsection{Materyal}

Çalışmada kullanılan malahit cevher örneği Tunceli ili Ovacık ilçesinden temin edilmiştir. Cevher laboratuvarda kırılarak, değirmende öğütülmüş ve daha sonra farklı parçacık boyutları elde etmek için standart elekler kullanılarak 115, 137, 163, 214 ve $335 \mu \mathrm{m}$ fraksiyonlarına ayrılmıştır. Malahit cevher örneğinin element analizi X-Ișınları Floresans Spektrometresi (XRF) ile yapılmış ve \%50,41 $\mathrm{SiO}_{2}, \% 15,23 \mathrm{ZnO}$, $\% 10,55 \mathrm{CuO}, \% 8,43 \mathrm{Fe}_{2} \mathrm{O}_{3}$ ve \%1,17 diğer oksitler ( $\mathrm{Na}, \mathrm{Ca}, \mathrm{K}, \mathrm{Mg}$, oksitler) olarak tespit edilmiştir. Örneğin kızdırma kaybı ise $800{ }^{\circ} \mathrm{C}$ 'de $\% 12,40$ olarak belirlenmiştir. Cevher örneğinin yapısal analizi ise X-Işınları Difraktometresi (XRD) ile yapılmış olup elde edilen sonuçlar sırasıyla
Şekil 1'de gösterilmiştir. Şekil 1'de verilen XRD spektrumunda görüldüğü gibi cevherin esas olarak kuvars $\left(\mathrm{SiO}_{2}\right)$, malahit $\left(\mathrm{CuCO}_{3} \cdot \mathrm{Cu}(\mathrm{OH})_{2}\right)$, smitsonit $\left(\mathrm{ZnCO}_{3}\right)$ ve siderit $\left(\mathrm{FeCO}_{3}\right)$ minerallerinden ibaret olduğu tespit edilmiştir.

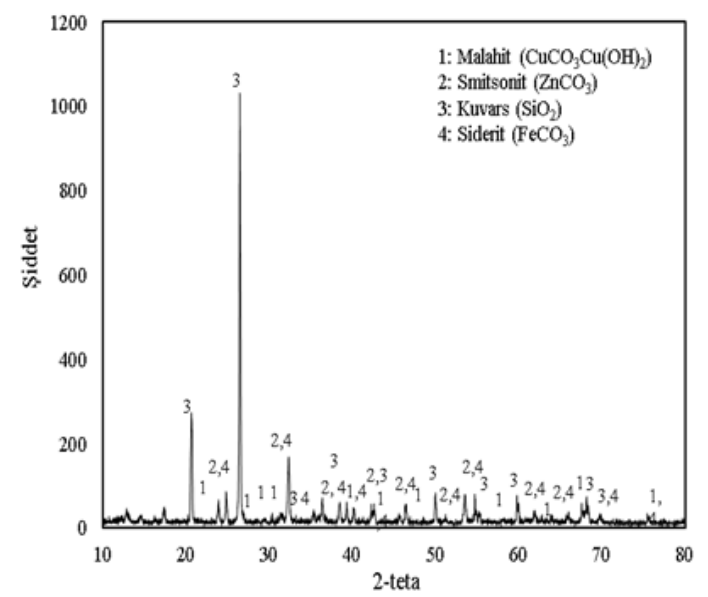

Şekil 1. Cevherin XRD spektrumu

\subsection{Metot}

Liç reaksiyonları 1 L hacimli ceketli bir cam reaksiyon kabında yapılmıştır. Reaktör içeriğini karıştırmak için bir mekanik karıştırıcı kullanılmıştır. Reaksiyon sırasında sıcaklığı sabit tutmak için bir sabit sıcaklık sirkülatörü kullanılmış ve özellikle yüksek sıcaklıklarda buharlaşmadan dolayı çözelti hacminin azalmasını engellemek için bir geri soğutucudan faydalanılmıştır. Her bir deneyde reaksiyon kabına derişimi bilinen $500 \mathrm{~mL}$ hacminde perklorik asit çözeltisi konulduktan sonra sabit sicaklık sirkülatörü vasıtasıyla çözelti sıcaklığı çalışma sıcaklığına getirilmiştir. Çözelti sabit sıcaklığa ulaştıktan sonra belirli katı/sıv1 oranına göre cevher örneği çözeltiye ilave edilmiş ve reaktör içeriği bilinen karıștırma hızında deney süresince karıştırılmıştır. Reaksiyonun ilerleyişi çözeltiye geçmiş olan bakır iyonlarının miktarı tespit edilerek izlenmiştir. Reaksiyon başladıktan sonra çeşitli zamanlarda reaktörden belirli hacimlerde örnekler alınarak cevherden çözeltiye geçmiş olan bakır miktarı kompleksometrik yöntemle tespit edilmiștir. Bakırın yanı sıra cevherin yapısındaki çinko ve demirin çözünme davranışını görmek için 
yapılan deneylerde çözeltiye geçmiş olan çinko ve demir miktarları da kompleksometrik titrasyonla belirlenmiştir. Katı fazdan çözeltiye geçmiş olan metal miktarları çözünme kesri cinsinden Eşitlik 1'e göre hesaplanmıştır.

Çözünme kesri $(X)=\frac{\text { Çözeltiye geçmiş olan metal miktarı }}{\text { Başlangıçta cevherdeki metal miktarı }}(1)$

Çizelge 1. Deney parametreleri ve değerleri

\begin{tabular}{|l|ccccc|}
\hline \multicolumn{1}{|c|}{ Parametre } & \multicolumn{5}{|c|}{ Değer } \\
\hline $\begin{array}{l}\text { Parçacık } \\
\text { boyutu, } \mu \mathrm{m}\end{array}$ & 115 & 137 & 163 & 214 & 335 \\
\hline $\begin{array}{l}\text { Kat1/sıv1 oranı, } \\
\text { g/mL }\end{array}$ & $1 / 500$ & $2 / 500$ & $3 / 500$ & $4 / 500$ & $5 / 500$ \\
\hline $\begin{array}{l}\text { Cözelti } \\
\text { derişimi, } \\
\text { mol/L }\end{array}$ & 0,01 & 0,02 & 0,03 & 0,04 & 0,05 \\
\hline $\begin{array}{l}\text { Karıştırma } \\
\text { hızı, rpm }\end{array}$ & 200 & 300 & 400 & 500 & 600 \\
\hline $\begin{array}{l}\text { Reaksiyon } \\
\text { sicaklığ } 1,{ }^{\circ} \mathrm{C}\end{array}$ & 20 & 30 & 40 & 50 & 60 \\
\hline
\end{tabular}

Liç deneylerinde çözelti derişimi, reaksiyon sıcaklığı, katı parçacık boyutu, katı/sıvı oranı ve karıştırma hızının malahit cevherinin çözünmesi üzerine olan etkileri incelenmiştir. $\mathrm{Bu}$ deney parametrelerinin değerleri Çizelge 1 'de gösterilmiştir.

\section{BULGULAR VE TARTIŞMA}

Deneyler de kullanilan cevherin bünyesinde esas olarak $\mathrm{CuCO}_{3} \cdot \mathrm{Cu}(\mathrm{OH})_{2}$ (malahit), $\mathrm{SiO}_{2}$ (kuvars), $\mathrm{ZnCO}_{3}$ (smitsonit) ve $\mathrm{FeCO}_{3}$ (siderit) bulunmaktadır. Liç reaktifi olarak kullanılan ve kuvvetli bir asit olan perklorik asit $\left(\mathrm{HClO}_{4}\right)$ suda çözündüğünde tamamen iyonlaşır. Bazik karaktere sahip olan malahit cevheri sulu çözeltideki $\mathrm{H}_{3} \mathrm{O}^{+}$ iyonu ile reaksiyon vererek çözünür ve cevherdeki bakır, çinko ve demir katı fazdan çözelti ortamına geçer. Cevherdeki malahit minerali ile perklorik asit arasındaki reaksiyon basitçe aşağıdaki gibi yazılabilir.

$$
\begin{aligned}
& \mathrm{HClO}_{4}+\mathrm{H}_{2} \mathrm{O} \rightarrow \mathrm{ClO}_{4}^{-}+\mathrm{H}_{3} \mathrm{O}^{+} \\
& \mathrm{CuCO}_{3} \cdot \mathrm{Cu}(\mathrm{OH})_{2}+4 \mathrm{H}_{3} \mathrm{O}^{+} \rightarrow 2 \mathrm{Cu}^{+2}+\mathrm{CO}_{2}+3 \mathrm{H}_{2} \mathrm{O}
\end{aligned}
$$

Toplam reaksiyon aşağıdaki gibi yazılabilir.

$\mathrm{CuCO}_{3} \cdot \mathrm{Cu}(\mathrm{OH})_{2}+4 \mathrm{HClO}_{4} \rightarrow$

$2 \mathrm{Cu}^{+2}+4\left(\mathrm{ClO}_{4}\right)^{-}+\mathrm{CO}_{2}+3 \mathrm{H}_{2} \mathrm{O}$

Esas liç deneyleri yapılmadan önce cevherin bünyesinde bulunan $\mathrm{Cu}, \mathrm{Fe}$ ve $\mathrm{Zn}$ 'nun perklorik asit çözeltilerinde çözünme davranışının nasıl olduğunu görmek için bazı ön denemeler yapılmıştır. Bu deneylerde karıştırma hızı, katı/sıv1 oranı ve parçacık boyutu sırasıyla $400 \mathrm{rpm}$, 2/500 $\mathrm{g} / \mathrm{mL}, 214 \mu \mathrm{m}$ değerlerinde sabit tutulmuş, perklorik asit derişimi ve reaksiyon sıcaklığ farklı değerlerde alınmıştır. Elde edilen deneysel veriler Şekil 2'de gösterilmiştir.

Birinci grup deneylerde, sicaklık $20{ }^{\circ} \mathrm{C}$ 'de sabit iken asit derişimi $0,01 \mathrm{~mol} / \mathrm{L}$ 'den $0,05 \mathrm{~mol} / \mathrm{L}$ 'ye arttırıldığında bakır, çinko ve demirin çözünürlüğünde artış olduğu Şekil 2 ve 3'den gözlenmektedir. Asit derişimi $0,01 \mathrm{~mol} / \mathrm{L}$ 'den $0,05 \mathrm{~mol} / \mathrm{L}$ 'ye arttırıldığında 90 dakikalık liç süresinde bakır çözünürlüğü \%38,5'den \%99'a, çinko çözünürlüğü ise \%29,3'den \%65,7'ye artmıştır. Aynı deney süresi için demir çözünürlüğü $0,01 \quad \mathrm{~mol} / \mathrm{L}$ asit derişiminde $\% 0,1,0,05 \mathrm{~mol} / \mathrm{L}$ asit derişiminde $\% 30,3$ olarak gerçekleşmiştir.

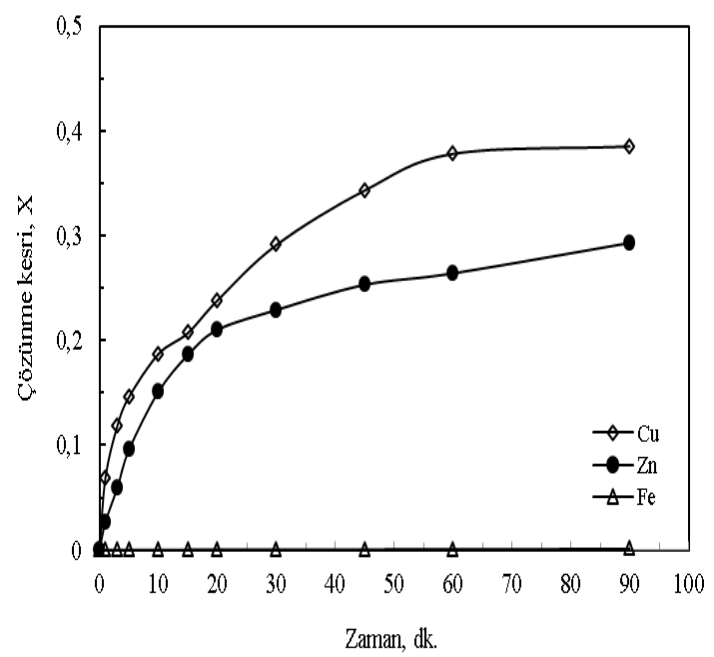

Şekil 2. Malahit cevherindeki $\mathrm{Cu}, \mathrm{Zn}$ ve $\mathrm{Fe}$ 'in $20{ }^{\circ} \mathrm{C}$ sicaklik ve $0,01 \mathrm{~mol} / \mathrm{L}$ perklorik asit çözeltinde çözünme kesri değerlerinin zamana karşı grafiği 


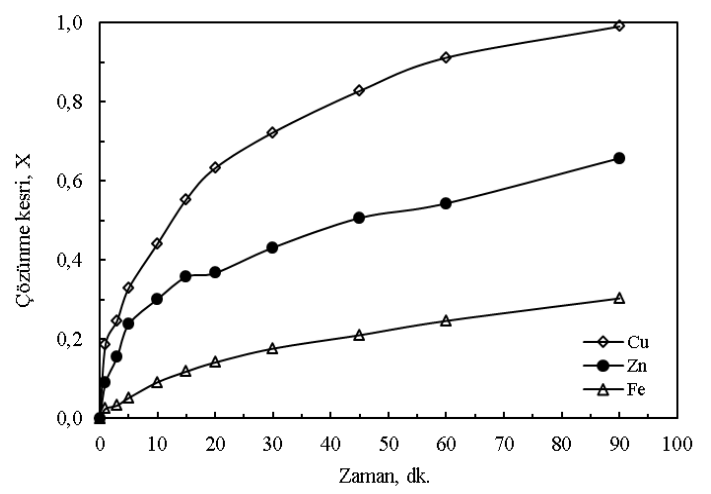

Şekil 3. Malahit cevherindeki $\mathrm{Cu}, \mathrm{Zn}$ ve Fe'in $20{ }^{\circ} \mathrm{C}$ sicaklik ve $0,05 \mathrm{~mol} / \mathrm{L}$ perklorik asit çözeltisinde çözünme kesri değerlerinin zamana karşı grafiği

İkinci grup deneylerde, sicaklık $60{ }^{\circ} \mathrm{C}$ 'de sabit tutularak derişim $0,01 \mathrm{~mol} / \mathrm{L}$ 'den $0,05 \mathrm{~mol} / \mathrm{L}$ 'ye arttırılmıştır. Şekil 4 ve 5 'den görüleceği gibi, sıcaklık $60{ }^{\circ} \mathrm{C}$ 'de sabit iken asit derişimin arttırılması bakır ve çinkonun çözünürlüğünde artışa sebep olmuş fakat demir çözünürlüğündeki artış daha yüksek oranda gerçekleşmiştir. Asit derişimi 0,01 mol/L iken 90 dakikalık liç süresinde bakır \%41,2, çinko \%31,6 ve demir \%1,8 düzeyinde çözünmüştür. Derişim $0,05 \mathrm{~mol} / \mathrm{L}$ 'ye arttırıldığında aynı liç süresi için bakır, çinko ve demir çözünürlüğü sirasıyla $\% 99,7, \quad \% 74,2$ ve \%41,5 olarak gerçekleşmiştir.

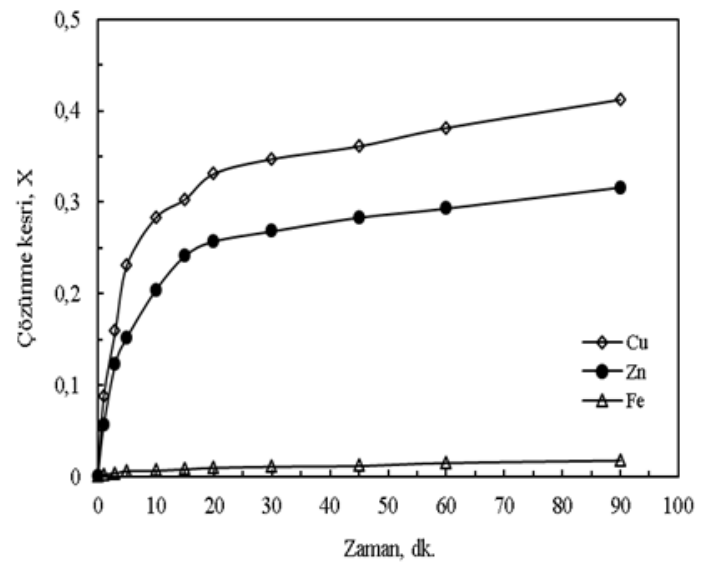

Şekil 4. Malahit cevherindeki $\mathrm{Cu}, \mathrm{Zn}$ ve $\mathrm{Fe}$ 'in $60{ }^{\circ} \mathrm{C}$ sicaklik ve $0,01 \mathrm{~mol} / \mathrm{L}$ perklorik asit çözeltisinde çözünme kesri değerlerinin zaman karşı grafiği
Bu sonuçlardan görüleceği gibi reaksiyon sıcaklığ sabit iken çözücü derişiminin arttırılması malahit cevherindeki bakır, çinko ve demir çözünürlüğü üzerinde oldukça önemli bir etkiye sahiptir. Asit derişiminin arttırılması bakır ve çinkoya nazaran özellikle demir çözünmesi üzerinde çok daha fazla bir etki göstermektedir. Esasen bu durum liç işlemi için olumlu olabilir. Zira asit derişiminin düşük tutulmasıyla 90 dakikadan biraz daha uzun reaksiyon sürelerinde cevherdeki bakır ve çinkonun tamamen çözünmesi temin edilebileceği gibi demirin ise ihmal edilebilecek düzeyde çözünmesi sağlanabilir. Bu ise liç çözeltilerinden bakır ve çinko kazanılmasında önemli bir avantaj sağlayabilir. $\mathrm{Bu}$ bulgu ile çalışmada kullanılan malahit cevherinden seçici liç gerçekleştirilerek bakır ve çinko kazanılabileceği söylenebilir.

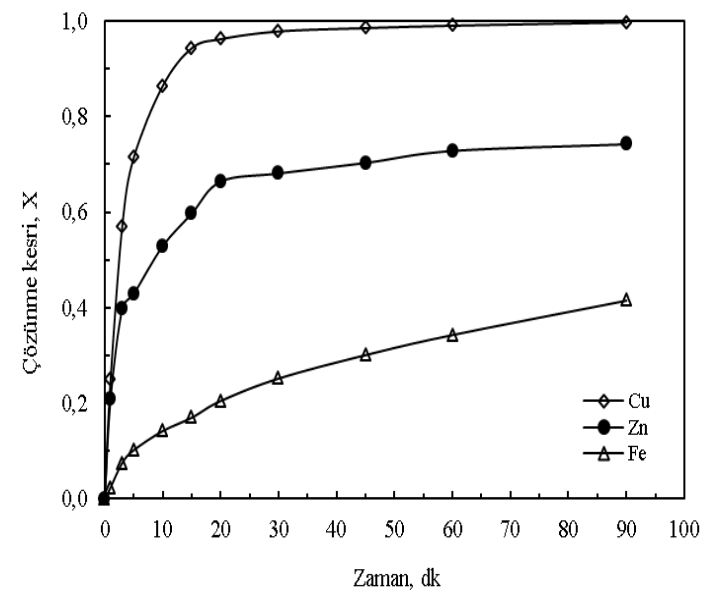

Şekil 5. Malahit cevherindeki $\mathrm{Cu}, \mathrm{Zn}$ ve Fe'in $60{ }^{\circ} \mathrm{C}$ sicaklık ve $0,05 \mathrm{~mol} / \mathrm{L}$ perklorik asit çözeltisinde çözünme kesri değerlerinin zamana karşı grafiği

Yukarıda verilen iki grup deney derişim sabit iken sıcaklığın arttırılması durumu için değerlendirilecek olursa benzer yorumlar aşağıdaki gibi yapılabilir. Derişim $0,01 \mathrm{~mol} / \mathrm{L}$ değerinde sabit iken sicakl1k $20{ }^{\circ} \mathrm{C}$ 'den $60{ }^{\circ} \mathrm{C}$ 'ye arttırıldığında bakır çözünürlüğünün \%38,5'den \%41,2'ye bir miktar arttı̆̆g, çinko çözünürlüğünün \%29,3'den \%31,6'ya çok az bir artış gösterdiği ve demir çözünürlüğünün ise $\% 0,1$ 'den $\% 1,8$ 'e arttığ1 tespit edilmiştir. Benzer değerlendirme $0,05 \mathrm{~mol} / \mathrm{L}$ sabit derişimde sicaklığın $20{ }^{\circ} \mathrm{C}$ 'den 
$60{ }^{\circ} \mathrm{C}^{\prime}$ ye artırıldığ 1 deneyler içinde yapılabilir. $\mathrm{Bu}$ deneylerde 90 dakikalık deney süresi sonunda bakır çözünürlüğünde \%99'dan \%99,7'ye çok az bir artış gözlenmiş olmakla birlikte hemen hemen aynı olduğu söylenebilir. Çinko çözünürlüğü ise $\% 65,7$ 'den \%74,2'ye yükselmiştir. Burada demir çözünürlüğü \%30,3'den \%41,5 değerine artış göstermiştir.

Derişim sabit iken sıcaklığın artırılması ile ilgili deneylerin sonuçlarından görüleceği gibi, sıcaklığın artırılmasının liç verimi üzerinde önemli bir etkisinin olmadığı söylenebilir. Her ne kadar reaksiyon sıcaklığının artmasıyla bakır, çinko ve demir çözünürlüğü artmış olsa bile, bu artış asit derişiminin etkisinin yanında daha düşük seviyede kalmaktadır. Bu durum liç çalışmasında önemli bir avantaj sağlayabilir. Çözünmenin sıcaklıktan fazla etkilenmemesi ile liç işlemleri düşük sıcaklıklarda gerçekleştirilebilir ve proseste daha az enerji harcanması sağlanabilir.

Böylece deney koşullarının kontrol edilmesiyle malahit cevherindeki bakırın tamamen çinkonun kısmen çözündürülebileceği ve demirin ise hemen hemen hiç çözünmeden cevherde kalmasının sağlanabileceği söylenebilir. Cevherdeki demirin düşük seviyelerde çözünmesi, liç işleminden sonra elde edilen çözeltisinin saflaştırılması için uygulanacak işlem basamaklarının sayısının azalmasını sağlayabilir. Ayrıca demir içermeyen bir çözeltiden bakır ve/veya çinko bileşiklerinin yüksek saflıkta kazanılması sağlanabileceği gibi, elektrolitik bir işlem uygulanacağı zaman akım veriminin de bundan olumlu etkilenmesi söz konusu olabilir. Her ne kadar düşük asit derişimlerinde çalışıldığında demirin çözünürlüğü çok düşük seviyelerde tutulabilse de, malahit cevheri bazik bir cevher olduğundan liç işlemi esnasında aşırı asit tüketimine sebep olabileceğinden bakır için yeterli çözünme değerlerine ulaşılamayabilir. Ayrıca düşük asit derişimlerinde liç hızı asit harcanmasından dolayı yavaşlayabilir ve yüksek bakır dönüşüm değerlerine ulaşmak için liç işlemini daha uzun sürelerde yapmak gerekebilir. Bu gibi sakıncaların önüne geçmek için deney parametrelerinin malahitin çözünmesi üzerine etkisinin incelendiği deneylerde $0,01 \mathrm{~mol} / \mathrm{L}$ asit derişiminden daha yüksek değerlerde çalışılmışken, sıcaklığın çözünme üzerinde çok fazla bir etkisinin olmaması sebebiyle düşük sıcaklık değerlerinde liç işlemleri gerçekleştirilmiştir.

Malahit cevherinin perklorik asit çözeltilerinde çözündürülmesinde deney parametrelerinin çözünme verimi üzerine olan etkileri incelenirken sadece bakırın çözünürlüğü izlenmiştir.

Malahit cevherinden bakır liçi üzerine perklorik asit derişiminin etkisi 0,01-0,05 $\mathrm{mol} / \mathrm{L}$ aralığında farklı asit derişimi değerlerinde incelenmiştir. Deneylerde diğer parametreler olan reaksiyon sıcaklığı, karıştırma hızı, katı/sıvı oranı ve katı tanecik boyutu ise sirasiyla $20{ }^{\circ} \mathrm{C}, 400 \mathrm{rpm}$, $2 / 500 \mathrm{~g} / \mathrm{mL}$ ve $214 \mu \mathrm{m}$ değerlerinde sabit tutulmuştur. Derişim etkisinin araştırıldı ğ deneylerden elde edilen veriler Şekil 6'da grafiğe geçirilmiştir. Söz konusu şekilden görüleceği gibi, perklorik asit derişiminin artması ile katı fazdan Sıvı faza geçen bakır miktarı artmaktadır.

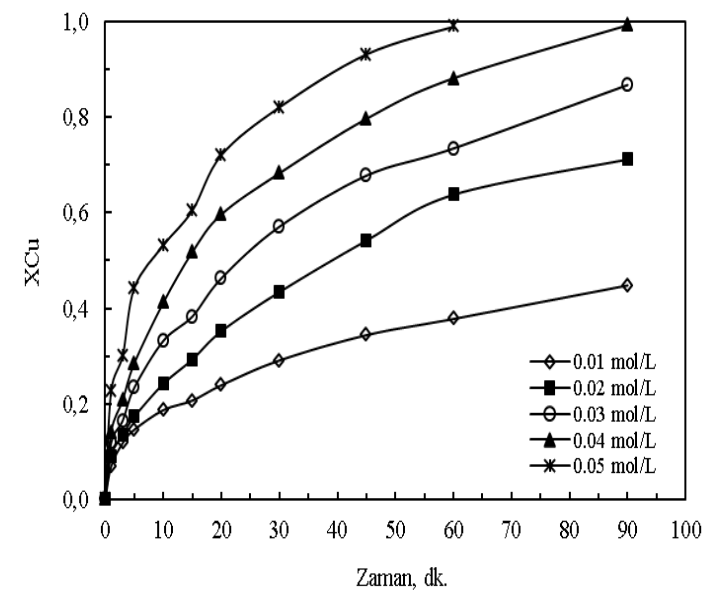

Şekil 6. Malahit cevherinden bakırın çözünmesi üzerine perklorik asit derişiminin etkisi

Reaksiyon hızı reaktanların derişiminin bir fonksiyonu olduğundan perklorik asit derişiminin artması ile malahitin çözünme hızı artmaktadır. Malahit cevheri bazik karaktere sahip olduğundan çözücü olarak kullanılan asidin harcanmasına sebep olur. $\mathrm{Bu}$ sebeple düşük asit derişimlerinde uzun sürelerde dahi yeterli çözünme değerlerine ulaşılamayabilir. Bununla birlikte asit derişiminin 
artmasıyla daha önce verilen Şekil 3 ve 5'den görüleceği gibi liç esnasında çözeltiye geçen demir miktarı artmaktadır. Bu durum liç çözeltisinin kirlenmesine sebep olur ve çözeltinin saflaştırılması için ilave işlemlerin yapılmasını gerektireceğinden proses ekonomisini olumsuz yönde etkileyebilir. Ayrıca çözeltiden elektroliz yoluyla bakır kazanılmasında aşırı enerji tüketimine sebep olabilir. Çözünen demir miktarını düşük tutmak buna karşılık bakır miktarını ise yüksek tutmak ve liç esnasında asit harcanmasının liç hızı üzerine etkisini en aza indirmek düşüncesiyle diğer parametrelerin etkileri incelenirken asit derişimi $0,04 \mathrm{~mol} / \mathrm{L}$ olarak alınmıştır.

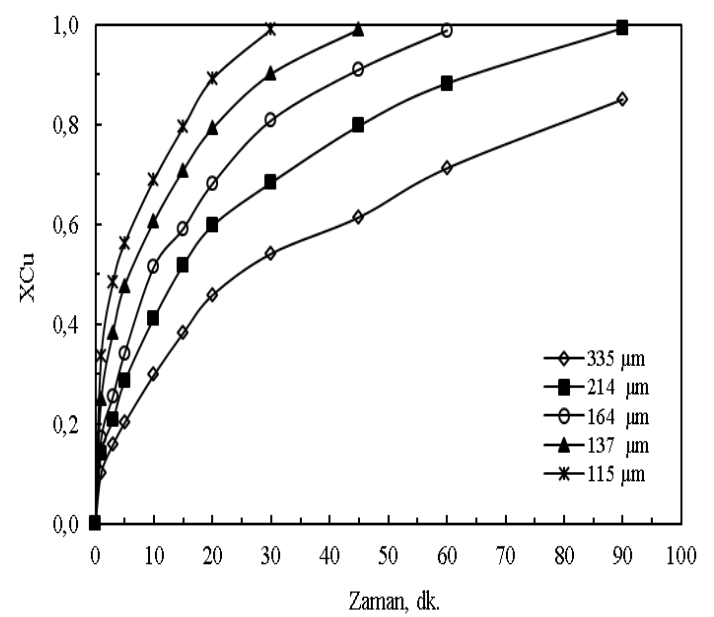

Şekil 7. Malahit cevherinden bakırın çözünmesi üzerine katı tanecik boyutunun etkisi

Malahit cevherinden bakırın çözünmesi üzerine ortalama katı parçacık boyutunun etkisi 335, 214, 164, 137 ve $115 \mu \mathrm{m}$ değerlerine sahip cevher örnekleri kullanılarak incelenmiștir. $\mathrm{Bu}$ parametrenin çözünme üzerine olan etkisi çalışılırken asit çözeltisi derişimi $0,04 \mathrm{~mol} / \mathrm{L}$, karıştırma hızı $400 \mathrm{rpm}$, reaksiyon sıcaklığ $120^{\circ} \mathrm{C}$ ve katı/sıv1 oranı ise $2 / 500 \mathrm{~g} / \mathrm{mL}$ değerlerinde sabit tutulmuştur. Deneylerden elde edilen çözünme kesri değerleri Şekil 7'de zamana karşı grafiğe geçirilmiştir. Şekil 7'den görüleceği üzere ortalama katı parçacık boyutunun küçülmesi ile bakırın çözünme kesri değerinin arttığ1 gözlenmektedir. Katı parçacıkların ortalama boyutu küçüldükçe taneciklerin toplam yüzey alanı ve dolayısıyla katı ile sıvı reaktanlar arasında temas yüzeyi büyüyeceğinden çözünme hızı artmış olur.

Malahit cevherinden bakırın çözünmesi üzerine kat1/sıv1 oranının etkisi 1/500-5/500 g/mL aralığında incelenmiştir. $\mathrm{Bu}$ deneylerde çözelti derişimi, reaksiyon sıcaklığı, karıştırma hızı ve parçacık boyutu sırasıyla $0,04 \mathrm{~mol} / \mathrm{L}, 20{ }^{\circ} \mathrm{C}$, $400 \mathrm{rpm}$ ve $214 \mu \mathrm{m}$ değerlerinde sabit tutulmuştur. Elde edilen deneysel bulgular Şekil 8'de grafiksel olarak gösterilmiştir. Şekil 8'den görüldüğü üzere katı/sıv1 oranının azalmasıyla bakırın çözünme kesri artmaktadır. Katı/sıvı oranının azalmasıyla çözücünün birim hacmi başına düşen tanecik miktarı azalacağından ve katı ile akışkanın teması iyileşeceğinden dolayı çözünme hızının artması beklenen bir sonuçtur. Ancak endüstriyel uygulamalarda mümkün olduğu kadar yüksek katı/sıvı oranlarında çalışılması istenir. Şekil 8'den görüleceği gibi, katı/sıvı oranının incelendiği deneysel şartlarda 90 dakika'llk liç süresi sonunda $2 / 500 \mathrm{~g} / \mathrm{mL}$ için \%99,3 çözünme değerine ulaşılmışken $5 / 500 \mathrm{~g} / \mathrm{mL}$ için bu değer \%79,4 olarak gerçekleşmiştir. Böylece yüksek katı/sıv1 oranları içinde kısa sürelerde makul bir liç verimine ulaşıldığı söylenebilir.

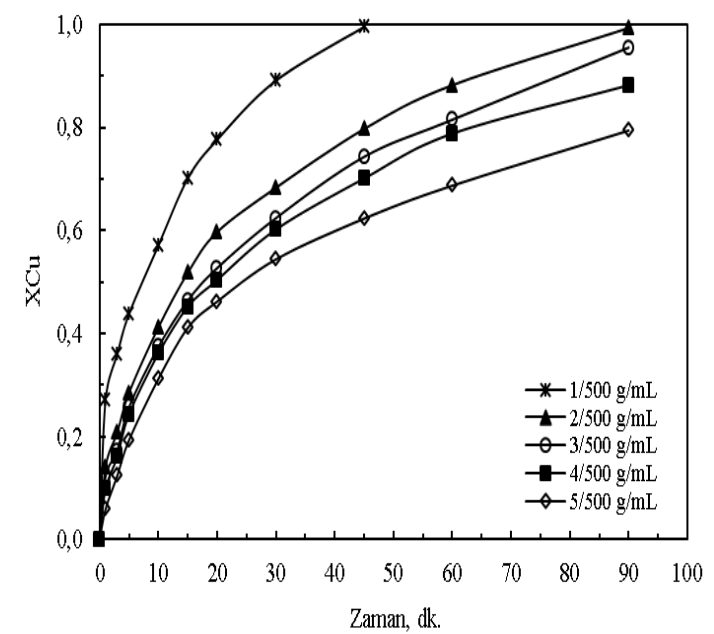

Şekil 8. Malahit cevherinden bakırın çözünmesi üzerine katı/sıvı oranının etkisi

Malahit cevherinden bakırın çözünmesi üzerine karıştırma hızının etkisi 200-600 rpm aralığında 
farklı karıștırma hızları uygulanarak incelenmiștir. Deneylerde perklorik asit derişimi $0,04 \mathrm{~mol} / \mathrm{L}$, katı/sıv1 oranı $2 / 500 \mathrm{~g} / \mathrm{mL}$, reaksiyon sicaklığ 1 $20{ }^{\circ} \mathrm{C}$ ve tanecik boyutu ise $214 \mu \mathrm{m}$ değerlerinde sabit tutulmuştur. $\mathrm{Bu}$ deneylerden elde edilen veriler Şekil 9'da grafiksel olarak gösterilmiştir. Şekil 9'dan gözlendiği gibi, reaktör içeriğinin karıştırılma hızı arttıkça malahitin çözünmesiyle çözelti ortamına geçen bakır miktarında da önemli oranda artış olmuştur. 200 rpm karıştırma hızında 90 dakika'lık liç süresinde cevherdeki bakırın ancak \%62,5'i çözünerek çözeltiye geçmişken, 600 rpm karıștırma hızında sadece 30 dakika'lık liç süresinde \%98,8 çözünme değerine ulaşılmıştır. $\mathrm{Bu}$ sonuçlardan da görüleceği gibi mevcut deneysel koşullarda karıştırma hızının malahitin çözünmesi üzerinde oldukça önemli bir etkiye sahip olduğu söylenebilir. Reaktör içeriğinin karıştırılmasıyla, katı reaktan etrafindaki durgun akışkan filminin kalınlığı azaltılmak suretiyle katı yüzeyine doğru diş difüzyon direnci azaltılmış olacağından çözünme hızında bir artış söz konusu olacaktır. Ayrıca karıştırma hızının arttırılması katı parçacıkların reaktör dibinde toplanmasını engellemiş olacak ve çözeltide asılı halde olmalarını sağlayacaktır. Bu durumda çözücü ile katı arasındaki temas iyileşeceğinden çözünme hızının artması söz konusu olacaktır. Mevcut çalışmada 400 rpm karıştırma hızında katı parçacıkların çözelti ortamında asılı halde oldukları gözlenmiştir

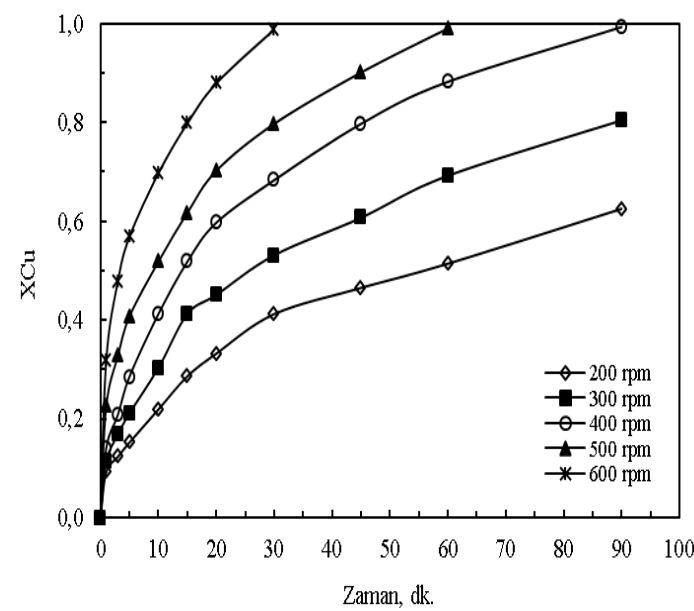

Şekil 9. Malahit cevherinden bakırın çözünmesi üzerine karıştırma hızının etkisi
Malahit cevherinden bakırın çözünmesi üzerine reaksiyon sıcaklığının etkisi $20-60{ }^{\circ} \mathrm{C}$ aralığında farklı sıcaklıklarda belirlenmiştir. Sıcaklık etkisi incelenirken perklorik asit çözeltisi derişimi 0,04 mol/L, karıştırma hızı $400 \mathrm{rpm}$, katı parçacık boyutu $214 \mu \mathrm{m}$ ve kat1/s1v1 oran1 2/500 $\mathrm{g} / \mathrm{mL}$ değerlerinde sabit tutulmuştur. Reaksiyon sıcaklığının etkisine ilişkin deney sonuçları Şekil 10'da gösterilmiştir. Zamana karşı bakırın çözünme kesri değerlerinin verildiği Şekil 10'dan görüleceği gibi reaksiyon sıcaklığının artmasıyla cevherden çözünerek çözeltiye geçen bakır miktarında artış olmaktadır. Sıcaklığın artmasıyla reaktan molekülleri daha hızlı hareket ederek birbirleriyle daha sık çarpışırlar ve bunun sonucunda moleküllerin reaksiyona girme olasılıkları artmış olur. Bir kimyasal reaksiyonun hızının sıcaklığa bağlılığı reaksiyonun hız sabiti ile belirtilir. Arrhenius teorisine göre reaksiyon hiz sabiti sıcaklığa üstel olarak bağlıdır ve bu bağlılıktan dolayı sıcaklıktaki küçük artışlar bile reaksiyon hızında önemli bir yükselmeye sebep olabilir.

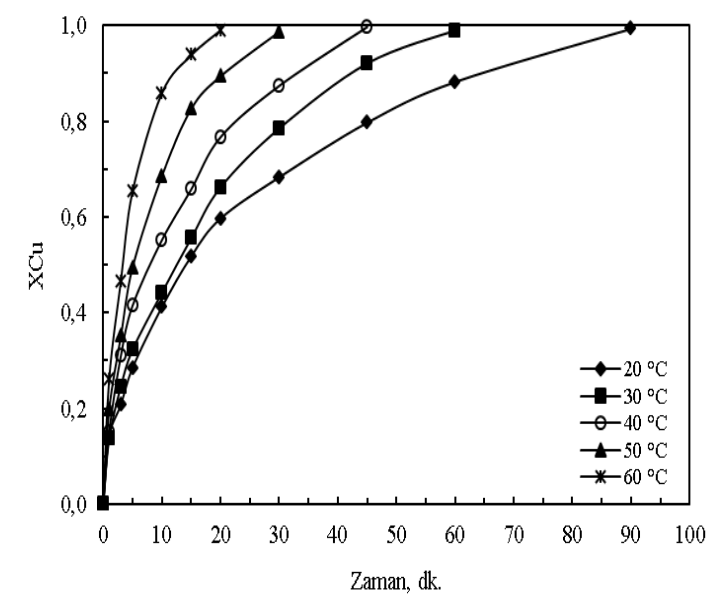

Şekil 10. Malahit cevherinden bakırın çözünmesi üzerine reaksiyon sıcaklığının etkisi

Liç reaksiyonları heterojen reaksiyonlar olduğundan bu tip proseslerin kinetik analizi genellikle katalitik olmayan katı akışkan heterojen reaksiyon modelleri kullanılarak yapılmaktadır. Bu modeller arasında büzülen çekirdek modeli liç reaksiyonlarının kinetik analizi için başarılı bir şekilde uygulanabilmektedir. Büzülen çekirdek 
modeline göre bir liç reaksiyonun hızı akışkan filminden difüzyon, kimyasal reaksiyon veya ürün tabakasından difüzyon basamaklarından biri veya birkaçı tarafindan kontrol edilebilir. Bu modeller için integre edilmiş hız ifadeleri Eşitlik (5-7)'deki gibi yazılabilir [18,19].

$\mathrm{x}=\mathrm{k}_{1} \cdot \mathrm{t} \quad$ (akışkan filminden difüzyon)

$1-(1-\mathrm{x})^{1 / 3}=\mathrm{k}_{\mathrm{r}} \mathrm{t}$

(kimyasal reaksiyon)

$1-3(1-\mathrm{x})^{2 / 3}+2(1-\mathrm{x})=\mathrm{k}_{\mathrm{d}} \cdot \mathrm{t}$

(ürün tabakasından difüzyon)

$\mathrm{Bu}$ eşitliklerde, $x$ dönüşüm kesrini, $k_{l}$ akışkan filminden difüzyon için görünür hız sabitini, $k_{r}$ yüzey kimyasal reaksiyonu için görünür h1z sabitini, $k_{d}$ ürün veya kül tabakasından difüzyon için görünür hız sabitini ve $t$ reaksiyon süresini temsil etmektedir. Deneysel olarak bulunan dönüşüm kesri değerleri kullanılarak Eşitlik 5, 6 ve 7'nin sol taraflarının $t$ zamanına karşı grafikleri çizildiğinde orijinden geçen düz doğrular hangi model için elde ediliyorsa reaksiyon hızını o basamak kontrol etmektedir. Bu çalışmada elde edilen deneysel verilere yukarıda sözü edilen modeller uygulandiğ 1 zaman orijinden geçen düz doğruların elde edilmediği görülmüştür. Literatürde, yukarıdaki modeller haricinde bu tür heterojen reaksiyonların kinetiğini açıklamak için karışık kinetik modeller de geliştirilmiştir [20]. Bu modeller deneysel verilere uygulandığı zaman perklorik asit çözeltilerinde malahitin liç kinetiğini ifade etmek için en uygun modelin integre edilmiş şekli Eşitlik 8'deki gibi yazılabilecek olan karışık kinetik modelin olduğu gözlenmiştir.

$\left[1-(1-\mathrm{x})^{2 / 3}\right]^{2}=\mathrm{k} . \mathrm{t}$

(karışık kinetik model)

Eşitlik 8 'de $x$ dönüşüm kesrini, $k$ reaksiyonun görünür hız sabitini ve $t$ reaksiyon süresini temsil etmektedir. Farklı reaksiyon sıcaklıkları için Eşitlik 8'in sol tarafının $t$ 'ye karşı grafiğe geçirilmesiyle elde edilen durum Şekil 11'de gösterilmiştir. $\mathrm{Bu}$ şekilden görüldüğü gibi orijinden geçen yüksek korelasyon katsayılı düz doğrular elde edilmiştir. Liç prosesinin aktivasyon enerjisini hesaplamak için Şekil 11'de görülen düz doğruların eğimlerinden görünür hız sabitleri $(k)$ belirlenmiş ve Şekil 12'de verilmiş olan Arrhenius grafiği oluşturulmuştur. Şekil 12'deki doğrunun eğiminden liç prosesi için aktivasyon enerjisi $30,94 \mathrm{~kJ} / \mathrm{mol}$ olarak hesaplanmıştır. Bu aktivasyon enerjisinin değerinden liç prosesinin difüzyon kontrollü olduğu ifade edilebilir.

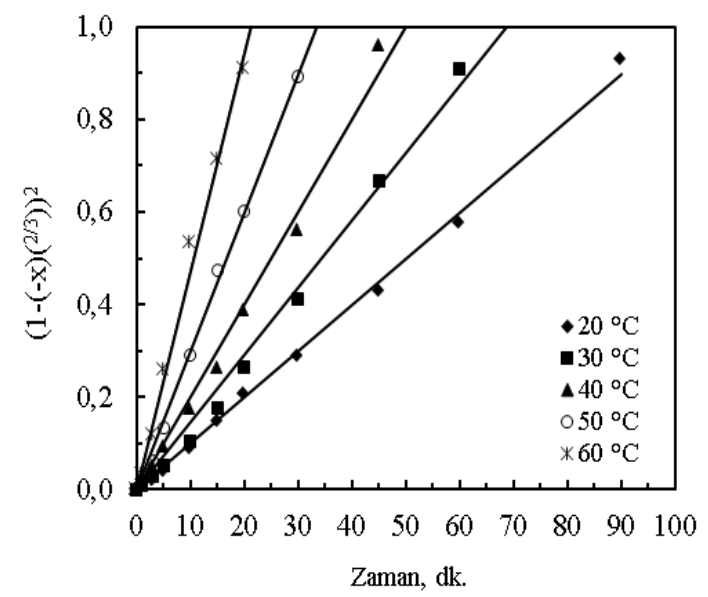

Şekil 11. Farklı sıcaklıklar için reaksiyon süresine karşı $\left[1-(1-\mathrm{x})^{2 / 3}\right]^{2}$ grafiği

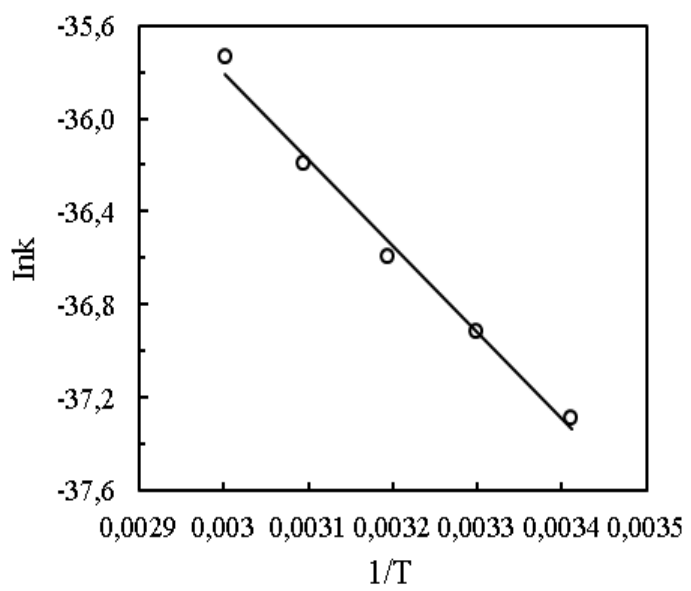

Şekil 12. Liç prosesi için Arrhenius grafiğgi

\section{SONUÇLAR}

$\mathrm{Bu}$ çalışmada, malahit cevherinin perklorik asit çözeltilerindeki çözünürlüğü incelenmiş ve cevherindeki bakır, çinko ve demirin çözünme 
davranışı belirlenmiştir. Cevherin liç işlemi üzerine asit derişimi, reaksiyon sıcaklığ katı tanecik boyutu, katı/sıvı oranı ve karıştırma hızının etkileri, cevherdeki bakırın çözünürlüğü izlenerek tespit edilmiştir. İncelenen bütün deneysel parametrelerin bakırın çözünmesi üzerinde önemli bir etkiye sahip oldukları gözlenmiştir. Asit derişimi, reaksiyon sıcaklığı ve karıştırma hızının artmasıyla, katı/sıvı oranı ve katı tanecik boyutunun ise azalmasıyla cevherdeki bakırın çözünürlüğünün arttığı tespit edilmiştir. Cevherdeki demirin çözünürlügünün asit derişiminden oldukça etkilendiği gözlenmiştir. Reaksiyon koşullarının kontrol edilmesiyle çözelti ortamına geçen bakır miktarının yüksek, demir miktarının ise düşük seviyelerde tutulabileceği belirlenmiştir. Liç prosesinin kinetik analizi sonucunda reaksiyon hızının karıșık kinetik modelle ifade edilebileceği belirlenmiştir. Proses için aktivasyon enerjisi 30,94 $\mathrm{kJ} / \mathrm{mol}$ olarak hesaplanmıştır. Elde edilen bulgulara göre perklorik asit çözeltilerinin malahit cevherinden bakırı seçici bir şekilde çözmek amacıyla kullanılabileceği söylenebilir.

\section{KAYNAKLAR}

1. Venkatachalam, S., 1998. Hydrometallurgy, Narosa Publishing House, India.

2. Han, K.N., 2002. Fundamentals of Aqueous Metallurgy, SME Inc., USA.

3. Naguman, P.N., 2008. The Chemistry and Kinetics of Oxidized Copper Sulfiding by Sodium Thiosulfate, Russ. J. Non-Fer. Met., 49, 433-437.

4. Tsogtkhankhai, D., Mamyachenkov, S.V., Anisimova, O.S., Naboichenko, S.S., 2011. Thermodynamics of Reactions During Nitric Acid Leaching of Minerals of a Copper Concentrate, Russ. J. Non-Fer. Met., 52, 135-139.

5. Cui, J., Zhang, L., 2008. Metallurgical Recovery of Metals from Electronic Waste: A Review, J. Hazard. Mater., 158, 228-256.

6. Song, S., Rao, F., Zhang, X., 2011. Effect of Morphology on Sulphuric Acid Leaching of Malachite Ores, Miner. Process. Extractive Metall., 120, 85-89.
7. Gupta, C.K., Murkherjee, T.K., 1990. Hydrometallurgy in Extraction Processes, CRC Press, USA.

8. Rosenqvist, T., 2004. Principles of Extractive Metallurgy, Tapir Academic Press, USA.

9. Bingöl D., Canbazoğlu, M., 2004. Dissolution Kinetics of Malachite in Sulphuric Acid, Hydrometallurgy, 72, 159-165.

10. Ata, O.N., Çolak S., Çopur M., 2001. Determination of the Optimum Conditions for Leaching of Malachite Ore in $\mathrm{H}_{2} \mathrm{SO}_{4}$ Solutions, Chem. Eng. Technol., 24, 409-413.

11. Künkül, A., Kocakerim, M.M., Yapıcı, S., Demirbağ, A., 1994. Leaching Kinetics of Malachite in Ammonia Solutions, Int. J. Miner. Process., 41, 167-182.

12. Oudenne, P.D., Olson, F.A., 1983. Leaching Kinetics of Malachite in Ammonium Carbonate Solutions, Metall. Trans. B., 14B, 33-40.

13. Ekmekyapar, A., Oya, R., Künkül, A., 2003. Dissolution Kinetics of an Oxidized Copper Ore in Ammonium Chloride Solution, Chem. Biochem. Eng. Q., 17, 261-266.

14. Lui, W., Tang, M.T., Tang, C.B., He, J., Yong, S.H., Yang, J.G., 2010. Dissolution Kinetics of Low Grade Complex Copper Ore in AmmoniaAmmonium Chloride Solution, Trans. Nonferr. Met. Soc. China, 20, 910- 917.

15. Liu, Z.X., Yin, Z.L., Hu, H.P., Chen, Q.Y., 2012. Leaching Kinetics of Low-Grade Copper Ore with High-Alkality Gangues in AmmoniaAmmonium Sulphate Solution, J. Cent. South. Univ., 19, 77-84.

16. Ekmekyapar, A., Aktaş, E., Künkül, A., Demirkıran, N., 2012. Investigation of Leaching Kinetics of Copper from Malachite Ore in Ammonium Nitrate Solutions, Metall. Mater. Trans. B., 43B, 764-772.

17. Künkül, A., Gülezgin, A., Demirkıran, N., 2013. Investigation of the Use of Ammonium Acetate as an Alternative Lixiviant in the Leaching of Malachite Ore, Chem. Ind. Chem. Eng. Q., 19, 25-35.

18. Wen, C.Y., 1968. Noncatalytic Heterogeneous Solid-Fluid Reaction Models, Ind. Eng. Chem., 60, 34-54.

19. Levenspiel, O., 1972. Chemical Reaction Engineering, John Wiley, New York. 
20. Dickinson, C.F., Heal, G.R., 1999. Solid-liquid Diffusion Controlled Rate Equation, Thermochim. Acta, 340-341, 89-103. 
